\title{
Ganglioneuroma arising in the pituitary fossa: a twenty year follow-up
}

\author{
RAOLD SEREBRIN, DAVID M ROBERTSON \\ From the Department of Pathology, Queen's University and Kingston General Hospital, Kingston, Ontario, \\ Canada
}

SUMmaRY A ganglioneuroma arising in the pituitary fossa is described. The lesion behaved as an indolent but progressive neoplasm rather than a hamartoma.

In 1964 one of us (DMR)' reported a case of a ganglioneuroma arising in the pituitary fossa. At that time the report served to demonstrate that the tumour was truly intrasellar and not attached to the hypothalamus. This relationship was not specified in the only case reported prior to that date. " Since then, further cases have been reported in this location and there has been a resurgence of interest in the biologic behaviour of these unusual ganglion cell lesions. ${ }^{+-n}$ In order to contribute to the understanding of their behaviour we submit a postmortem follow-up of our original case report.

\section{Case report}

In February 1963 a 45-year-old housewife presented with a five year history of headaches. Neurologic examination, including perimetry, was unremarkable; the impression was that she had tension headache. A skull radiograph revealed an enlarged sella turcica with an intact floor and a pneumoencephalogram indicated a small suprasellar extension of an intrasellar mass. A right frontal craniotomy was performed. A meaty, red tumour was seen to rise up out of the sella between the optic nerves and enfold the anterior aspect of the optic chiasm. The tumour was removed in piecemeal fashion; it proved not to be attached to the hypothalamus.

Address for reprint requests: Dr David M Robertson, Department of Pathology, Queen's University, Kingston, Ontario K7L 3N6. Canada.

Received 12 July 1983. Accepted 6 August 1983
Microscopically the bulk of the specimen consisted of ganglion cells and their processes. Smaller cells without identifiable cytoplasm (presumed to be glial in nature) were also noted. Ultrastructural evidence of synapse formation was present.

The patient was placed on thyroxine and prednisone postoperatively. She remained well for the next nineteen and one-half years except for occasional headaches. No neurological deficits were noted. She died in July 1982 as a result of salicylate overdose at the age of 65 years.

\section{Post-mortem neuropathological findings}

Adhesions were present between the sella turcica and the optic chiasm. When these were lysed a discrete pituitary stalk was identified. After removal of the brain, the sella turcica appeared empty; neither residual tumour nor pituitary tissue could be identified. The bony floor of the sella was absent. Adherent to the sphenoid bone directly below the pituitary fossa was a firm, grey rounded mass measuring $8 \times 10 \mathrm{~mm}$.

\section{Microscopic findings}

The bony floor of the sella had been completely eroded by tumour (fig, a). Tumour was present both in compact form and also dispersed in clumps of cells which were widely scattered against the partially eroded mucosal lining of the enlarged sphenoid in sinuses. Microscopically the tumour occupied an area of 4 to $5 \mathrm{~cm}$ in greatest diameter. The cellular architecture was as previously described. Large multipolar and multinucleate ganglion cells and their axions comprised the bulk of the tumour (fig, b). Widely dispersed fragments of adenohypophyseal tissue were identified with immunoperoxidase stains directed against human growth hormone, prolactin and ACTH. These fragments were sandwiched between the tumour and the bony side walls of the sphenoid. Small cells with dark round nuclei and without discernible cytoplasm were again present. These cells did not stain with GFAP or PTAH stains; hence their 


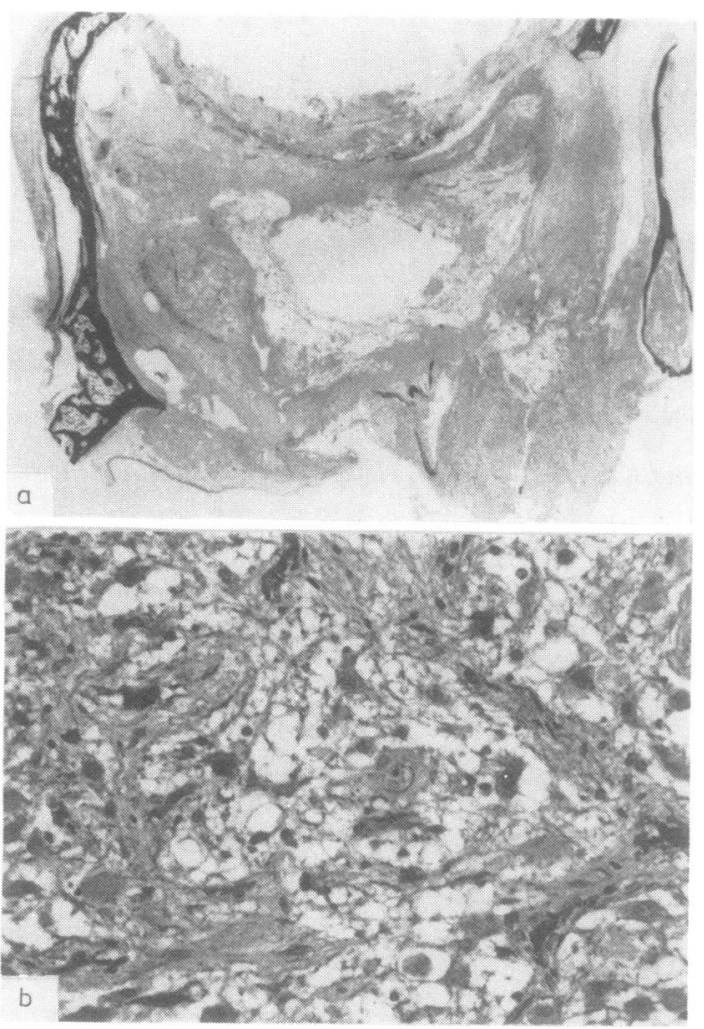

Fig (A) A coronal section of the midportion of the hypophyseal fossa shows the absence of a bony floor. Tumour fills the sphenoid sinuses (HPS $\times 4.5$ ), (B) The tumour is composed of neurons distributed in a fibrillar stroma. Some neurons have large vesicular nuclei, prominent nucleoli and abundant cytoplasm. Other neurons are multinucleate. Processes arising from cell bodies extend into the surrounding tissue. Small, dense nuclei of indeterminate nature are also present. $($ HPS $\times 110)$.

glial nature remains uncertain. Myelin stains were negative, and collagen was very sparse. No mitotic activity was noted.

The hypothalamus, optic nerves, chiasm and tracts were normal, as was the remainder of the brain.

\section{Discussion}

Ganglioneuromas have been variously regarded as true neoplasms and as hamartomas. This case illustrates that a ganglioneuroma in this location may behave as a truly progressive neoplasm with an exceedingly indolent course. Such behaviour runs contrary to the opinion of some workers that mature ganglion cell tumours are more appropriately considered hamartomatous in nature. Nevertheless the growth of these lesions is difficult to explain if one accepts that mature ganglion cells are incapable of cell division. Secondly, although neoplastic transformation of these lesions is well recognised, when it occurs it usually takes place within the astrocytic element, an element not identified in our case. Finally, although transitional forms of tumours containing primitive neural elements have been demonstrated, no features were present in our case to suggest dedifferentiation into more primitive neuroblastic elements.

\section{References}

'Robertson DM, Hetherington RF. A case of ganglioneuroma arising in the pituitary fossa. $J$ Neurol Neurosurg Psychiatry 1964;27:268-72.

' Benda C. Beiträge zur normalen und pathologischen morphologie der Hyperphyse. Verh Disch Ges Pathol 1927;22:185.

'Casper J. Ueber neurogene geschwulste im hinterlappen der Hypophyse. Zentralb Allg Pathol 1933;56:404.

${ }^{4}$ Rhodes R, Dusseau J, Boyd A, Knigge K. Intrasellar neural-adenohypophyseal choristoma-a morphological and immunocytochemical study. $J$ Neuropathol Exp Neurol 1982;41, 3:267-80.

${ }^{5}$ Scheithauer BW, Kovacs K, Randall R, Horvath E, Okazaki H, Laws ER. Hypothalamic neuronal hamartoma and adenohypophyseal neuronal choristomatheir association with somatotrophic pituitary adenoma. J Neuropathol Exp Neurol 1983;42:306.

- Ilgren E, Briggs M, Aynsley-Green M. Precocius puberty in a 3-year-old girl associated with a parasellar ganglionic hamartoma. Clin Neuropath 1983;2:95-8. 